\title{
Comparative study on the effect of Thaumatococcus daniellii (Benn) Benth sweetener on the Physicochemical and Sensory Properties of Sorghum based Kunun-zaki Drink
}

\author{
*11OJO, A; ${ }^{2}$ ENUJIUGHA, VN; ${ }^{2}$ AYO-OMOGIE, HN; ${ }^{3}$ ABIODUN, OA
}

\author{
${ }^{l}$ Department of Food Science and Technology, Osun State Polytechnic, Iree, Nigeria, ${ }^{2}$ Department of Food Science and Technology, \\ Federal University of Technology, Akure, Nigeria, ${ }^{3}$ Department of Home Economics and Food Science, University of Ilorin, Ilorin, Kwara \\ State, "ayo_ojo62@yahoo.com, Funmiabiodun2003@yahoo.com
}

\begin{abstract}
Effect of a natural sweetener (Thaumatococcus danielli) on the physicochemical properties and sensory evaluation of kunun-zaki was determined. Proximate and mineral compositions of the natural sweetener, physicochemical properties and sensory evaluation of kunun-zaki using Thaumatococcus danielli and sucrose were determined. Proximate composition of the aril showed that protein had $(33.03 \%)$, crude fibre $(5.20 \%)$, ash content (4.79\%), moisture content $(12.20 \%)$, fat content $(0.16 \%)$, and carbohydrate $(44.17 \%)$. The result of mineral obtained for the aril showed the following values potassium (190.00ppm), sodium (167.66ppm), calcium (132.96 ppm), iron $(21.59 \mathrm{ppm})$ and magnesium (14.40 ppm). Physicochemical composition of kunun-zaki varied with concentrations of Thaumatococcus danielli aril and sucrose $\mathrm{pH}$ ranged between (3.90-4.90), total solid (4.95-13.49 \%) and titatable acidity $(0.78-0.39 \%)$ for Thaumatococcus danielli while kunun-zaki sweetened with sucrose had $\mathrm{pH}(3.51-4.90)$, total Solids (4.95-7.43\%) and titratable acidity (0.74-0.85) respectively. The sensory evaluation showed that the samples sweetened with Thaumatococcus daniel aril compared favorably with sucrose in terms of colour, taste, aroma and overall acceptability. (C) JASEM

https://dx.doi.org/10.4314/jasem.v21i6.13
\end{abstract}

Keywords: Kunun-zaki, Proximate, Mineral, Sensory properties, Thaumatococcus danielli,

Kunun-zaki is a traditionally fermented non-alcoholic beverage that originated from the northern part of Nigeria, which can be produced either from millet, sorghum or maize. Kunun-zaki is a Hausa word meaning "sweet beverage", it is now widely consumed in several parts of Nigeria owning to its refreshing qualities (Osuntogun and Aboaba, 2004). Kunun-zaki is generally acceptable and used as substitute for alcoholic drinks (Gaffa and Ayo, 2002). There are several types of kunun-zaki but few have been reported in literature; kunun-zaki, kununtsamiyat, kunun-gyada (Nkama et al., 1995) and kunun-akamu (Oyeyiola, 1991). Others include kunun-baule, kunun-jiko and kunun-gayamba (Amusha and Ashaye, 2009). Kunun-zaki is the most preferred among the kunun types, reported in the literature Gaffa et al. (2002). Although production of kunun-zaki is in small scale level, the beverages are widely sold in the local market and at resorts. Gaffa et al., (2002) reported that $73 \%$ of the population in Nigeria consumes kunun-zaki daily and 26\% occasionally. The product cost less compared to conventional carbonated beverages but the products are not usually properly packaged. The product is offered in cups, transparent polyethylene sachets, plastics and glass containers for retail sales. Consumption is all year round with peak production in the season (February-July) when the beverage is served preferably chilled. The production process of kunun-zaki is done with local household utensils with processes varying between individuals, households and localities (Adeyemi and Umar, 1994)
The use of natural sweeteners in food products is encouraged in food industry. Artificial sweeteners like saccharin, aspartame, cyclamate and Acesulfame $\mathrm{K}$ are used world-wide as low caloric sweeteners by patients affected by disease linked to the consumption of sugar, e,g diabetics, hyperlipemia ,caries, obesity etc. but they have side effects such as psychological problems, metal disorders, bladder cancer, heart failure and brain tumors ( Hagiwara et al., 1984; Nabors, 1988; Kanarek, 1994; Cohen, 2001; Weihrauch et al., 2002). Sweet protein have the potential to replace these artificial sweeteners by acting as natural good low calories sweeteners, as we know proteins do not trigger demand for insulin in the patients whereas sucrose does. There are seven known sweet and taste modifying proteins, namely Brazzein, Thaumatin, Curculin, Mabinlin, Miraculin and Pertaclin (Faus, 2000). Thaumatin is a low calories intensely sweet- tasty protein (Raimi et al., 2011) and flavour modifier (Green, 1999). It consists of 207 amino acids with eight intramolecular disulfide binds and contains no free cysteine residues (Kant, 2005). The aril is of an intensely sweet, nontoxic and heat stable protein. Thaumatin is extracted, used as desserts, chewing gums and pet foods. The seeds of Thaumatococcus danielli also produce a jelly that swells (entrap water) to 10 times its own weight and hence provide a substitute for agar (Yeborah et al., 2003). The thaumatin are first sweettasting proteins that have been found in nature and the crystals are about 2000-3000 times sweeter than sucrose and neither allergic nor mutagenic or teratogenic (Yeborah et al., 2003). Thaumatin has 
been approved for use in many countries as both a flavor enhancer and a high- intensity sweetener (Zemanek and Wasserman, 1995). Therefore, this work determines the effect of a natural sweetener (Thaumatococcus danielli) on the physicochemical and sensory properties of kunun-zaki.

\section{MATERIALS AND METHODS}

Materials: Pearl millet, sorghum, sucrose were purchased from Sabo market in Osogbo, Osun State. Thaumatocuccusdanielliwas obtained from a farm at Esa-odo,Osun State, Nigeria.

Methods, Production of kunun-zaki: The modified method of Ayo et al. (2013) was adopted for processing of kunun-zaki. One kilogram $(1 \mathrm{~kg})$ of cleaned sorghum grains were washed and steeped in clean water for $48 \mathrm{~h}$ to soften the seed. The grains were washed to remove stones and wet milled and no spices were added into the slurry. Two-third of the slurry was mixed with $2500 \mathrm{ml}$ of boiling water and stirred to form a gel; this was allowed to cool for $3 \mathrm{~h}$. The remaining one-third of the slurry was added to the gel, mixed with cold boiled water $(1000 \mathrm{ml})$ and left open to ferment for $12 \mathrm{~h}$ ). It was then sieved with a muslin cloth and the filtrate was sweetened with miracle fruit (Thaumatococcus danielli) and sucrose. The sweetener (Thaumatocuccus danielli) and sucrose were added to kunun zaki at different concentrations $(2.5,5.0,7.5,10.0,12.5$, and $15.0 \mathrm{~g})$ while other ingredients were maintained at constant level.

\section{ANALYSES}

Proximate Analysis: Determination of Moisture Content: A clean glass Petri-dish to be used was oven dry for about 30 minutes, and then cooled in desiccators. The cooled Petri-dish was weighed as $\mathrm{W} 1$ and $2 \mathrm{~g}$ of the sample was placed into the Petri dish and heated in the oven at $105{ }^{\circ} \mathrm{C}$ for 5hours, this was done until a constant weight obtained. Then the moisture content of sample was calculated.

Determination of Crude Protein: Sample (2 g) was weighed into the Kjedahl digestion flask to ensure that all sample material get to the bottom of the flask. Kjedhal catalyst (0.5 g copper sulphate and $10 \mathrm{~g}$ sodium sulphate) was added to the sample and $25 \mathrm{ml}$ of concentrate sulfuric acid was also added to sample and then fixed for 3 hours in the digestion unit. The digest, a pure green solution after cooling was then change into a colourless liquid that was transferred into $250 \mathrm{ml}$ volumetric flask and made up to mark with distilled water.

$5 \mathrm{ml}$ portion of the digest above was pipette into the body of the apparatus via the small funnel aperture followed by $10 \mathrm{ml}$ of $40 \% \mathrm{NaOH}$ into the same funnel, $20 \mathrm{ml}$ of $4 \%$ boric acid indicator was pipette into conical flask and left to heat. The steam exit off the distillatory was closed and the change of colour of boric acid indicator to green was timed. The mixture was distilled for $15 \mathrm{~min}$ in accordance with (AOAC, 1990). The green colour solution obtained was then titrated against $0.01 \mathrm{~N}$ HCL contained in a $50 \mathrm{ml}$ burette. At the point, the green colour turns to blue which indicate that all nitrogen trapped as ammonia borate $\left[\left(\mathrm{NH}_{4}\right)_{2} \mathrm{BO}_{3}\right]$ have been removed as ammonium chloride $\left(\mathrm{NH}_{4} \mathrm{CL}\right)$. The protein content was calculated from the relationship below

$$
\text { Total protein }(\%)=\frac{\text { Titre value } x \text { Normality of acid } x 0.014 \times 250 \times 100}{\text { Ml of digest } x \text { Wt of sample }}
$$

Dermination of Ash Content: Sample (2 g) was weighed into a porcelain crucible with known weight and the weight was recorded and then transferred into the muffle furnace set at $550^{\circ} \mathrm{C}$ for 4 hours. After ashing, the crucibles were cooled to about $105^{\circ} \mathrm{C}$ in a forced air oven before cooling them further to room temperature in a desiccator. The crucibles and their content were weighed, and weight recorded as percentage ash content and calculated from the relationship below.

$$
\text { Ash }(\%)=\frac{\text { Weight of crucible }+ \text { ash }- \text { weight of crucible }}{\text { Wt of sample }} \times 100
$$

Crude Fat Determination: The flour samples from moisture determination were transferred to a $22 \times 80 \mathrm{~mm}$ paper thimble. A small ball of cotton wool or glass wool was put into the thimble to prevent loss of sample. Anti-bumping granules were added to a previously dried $250 \mathrm{ml}$ round bottom flask and weighed. $150 \mathrm{ml}$ of petroleum spirit was added to the flask and apparatus was assembled. A quick fit condenser was connected to the soxhlet extractor and refluxed for six hours on low heat. The flask was removed and evaporated on a steam bath. The flask with the fat was heated for 30 mins in an oven for 
$103^{\circ} \mathrm{C}$. The flask and its content were cooled to room temperature in desiccators after which it was weighed and percentage fat was calculated. (AOAC, 1990)

Determination of Crude Fibre: Two gram (2g) of the de-fatted sample was accurately measure into the fibre flask and $100 \mathrm{ml}$ of $0.255 \mathrm{~N} \mathrm{H}_{2} \mathrm{SO}_{4}$ was added. The mixture was heated for $30 \mathrm{~min}$ with the heating mantle. The hot mixture was allowed to cool and then filtered through a filter paper. The filtrate obtained was thrown off and the residue was returned to the fibre flask to which $100 \mathrm{ml}$ of $0.313 \mathrm{~N} \mathrm{NaOH}$ was added and heated for another 30mins. The mixture was cooled and filtered through a filter paper. The filter paper plus the residue was transferred into a crucible and oven dried at $105^{\circ} \mathrm{C}$ for 3 hours to drive off moisture. The oven dried crucible containing the filter paper plus was cooled in a desiccators and later weighed to obtain $\mathrm{W}_{1}$. The crucible with $\mathrm{W}_{1}$ will then be transferred to the muffle furnace for ashing at $550^{\circ} \mathrm{C}$ for 4 hours. The crucible containing white or grey ash (free of carbonaceous material) was cooled in the desiccator and weighed to obtain $\mathrm{W}_{2}$. The difference $\mathrm{W}_{1}-\mathrm{W}_{2}$ gives the weight of fibre. Then was calculated with the relationship below

Crude fibre $(\%)=\frac{\text { Dry wt of residue before ashing }- \text { wt of residue after ashing }}{\text { Wt of sample }} \times 100$

Determination of Carbohydrate: The carbohydrate content was determined using the AOAC (2005) method. The content was estimated by difference. $\%$ Total carbohydrate $=100-(\%$ water $+\%$ protein $+\%$ fat $+\%$ ash $+\%$ crude fibre)

Mineral Analysis: Flour sample (0.5 g) was weighed into a clean ceramic crucible. A blank was prepared with empty crucible. The crucible was placed in a muffle furnace at $500{ }^{\circ} \mathrm{C}$ for $4 \mathrm{hr}$. The sample was allowed to cool down in the oven after which it was removed carefully. The ashed sample was poured into already labeled $50 \mathrm{~mL}$ centrifuge tube. The crucible was rinsed with $5 \mathrm{~mL}$ of distilled water into the centrifuge tube. The crucible was rinsed again with $5 \mathrm{~mL}$ of aqua regia. This was repeated to make a total volume of $20 \mathrm{~mL}$. The sample was mixed properly and centrifuged (IEC Centra GP8) for 10 min at $301.86 \mathrm{~g}$. The supernatant was decanted into clean vials for mineral determination. The absorbance was read on UV-spectrophotometer (BK-UV1600PC Model) at different wavelength for each mineral

TTA (\%)

$=\frac{N(\mathrm{NaOH}) \times \text { titre value } x \text { lactic acid value } x \text { dilution factor }}{10} \times 100$

Where: $\mathrm{N}=$ normality of $\mathrm{NaOH}(0.01)$, Lactic acid value $=0.09$, Dilution factor $=10$

Sensory evaluation: Sensory quality attributes of kunun-zaki was assessed using 20 panelists. Colour, flavour, taste and general acceptability were based on 9-point Hedonic scale (Iwe, 2000). The rating of the sample ranged from 1 (dislike extremely) to 9 (like extremely).

Statistical Analysis: Data obtained were analysed using One-way Analysis of Variance (ANOVA) using the SPSS (version 17.0) and statistical element (Ca-422.7 nm, Fe-248.3 nm, Mg-285.2 nm, Na-589 $\mathrm{nm}$ and K-766.5 nm) (Novozamsky et al., 1983).

Physicochemical properties of Kunun-zaki: $\mathrm{pH}$ of the juice was measured using digital $\mathrm{pH}$ meter (ELICO L1 $614 \mathrm{pH}$ analyser) and expressed as $\mathrm{pH}$ units. Total soluble solids (TSS) as \% Brix was determined using digital ATAGO refractometer (ATAGO, PAL-Maple Pocket type).

Titratable acidity: It was determined using the AOAC (2000) method. Sample (30 ml) was filtered into a $100 \mathrm{ml}$ standard volumetric flask. The filtrate was made up to $100 \mathrm{ml} .10 \mathrm{ml}$ of the filtrate was pipetted into a beaker and 1 drop of phenolphthalein was added. The mixture was then titrated against the standard $0.01 \mathrm{~N}$ sodium hydroxide solution until a light pink colour was attained. The reading of the burette was recorded. This was done in duplicates.

significance was accepted at 0.05 level of probability. Duncan new multiple test was used to determine difference among means.

\section{RESULTS AND DISCUSSION}

Proximate composition of aril of Thaumatococcus danielli: The proximate composition of Thaumatococcus danielli aril is shown in Table 1. The aril had low moisture (12.20\%). The moisture content of fruit is very important for it shelf life, since the lower the moisture, the better it storage stability (Butt, et al., 2004). The ash was $4.79 \%$ which indicate high level of minerals in the aril. Fibre, fat, carbohydrate and protein contents were $5.20 \%, 0.61 \%, 44.17 \%$ and $33.05 \%$ respectively. The 
aril had high protein content, which made it a suitable substitute for sucrose.

\begin{tabular}{lr} 
Table 1: Proximate composition of Thaumatococcus danielli \\
\hline Parameter $(\%)$ & \multicolumn{1}{c}{ Aril } \\
\hline Moisture content & $12.20 \pm 0.02$ \\
Ash content & $4.79 \pm 0.06$ \\
Fiber content & $5.20 \pm 0.09$ \\
Fat content & $0.61 \pm 0.04$ \\
Protein content & $33.03 \pm 0.11$ \\
Carbohydrate & $44.17 \pm 0.20$ \\
\hline Mean \pm Standard deviation &
\end{tabular}

Mineral composition of Thaumatococcus dannielli aril: Table 2 showed the mineral composition of Thaumatococcus dannielli aril. The most abundant mineral in the fruit aril is potassium (190.63ppm) which was in accordance with the report of Oshodi et al. (1999) that potassium is the most abundant mineral in Nigeria agricultural products. Potassium and sodium are required to maintain osmotic balance of body fluid $\mathrm{pH}$ of the body, regulate muscle and nerve irritability, control glucose absorption and enhance normal retention of protein during growth (NRC, 1989). Also, values of sodium, calcium, Iron, magnesium were $167.66 \mathrm{ppm}, 132.96 \mathrm{ppm}, 21.59 \mathrm{ppm}$ and $14.40 \mathrm{ppm}$. The values of mineral contents are dependent on the following factors season, species, soil types, cultural practices adopted during planting (Nkama, et al., 1995).

Table 2: Mineral composition of Thaumatococcus danielli aril

\begin{tabular}{ll}
\hline Parameter $(\mathrm{ppm})$ & Aril \\
\hline Potassium & $190.63 \pm 0.72$ \\
Sodium & $167.66 \pm 1.48$ \\
calcium & $132.96 \pm 1.76$ \\
Iron & $21.59 \pm 0.94$ \\
Magnenium & $14.40 \pm 0.21$ \\
\hline
\end{tabular}

Table 3: Physicochemical composition of kunun-zaki sweetened

\begin{tabular}{llll}
\multicolumn{3}{c}{ with sucrose } \\
\hline Sample $(\mathrm{g})$ & $\mathrm{pH}$ & Total solids & Titratable acidity \\
\hline 2.5 & $3.90^{\mathrm{d}} \pm 0.1$ & $9.15^{\mathrm{c}} \pm 0.22$ & $0.93^{\mathrm{c}} \pm 0.04$ \\
5.0 & $4.00^{\mathrm{cd}} \pm 0.00$ & $10.23^{\mathrm{c}} \pm 0.14$ & $0.82^{\mathrm{c}} \pm 0.28$ \\
7.5 & $4.15^{\mathrm{bcd}} \pm 0.07$ & $10.10^{\mathrm{c}} \pm 0.14$ & $0.78^{\mathrm{c}} \pm 0.02$ \\
10.0 & $4.40^{\mathrm{bcd}} \pm 0.14$ & $10.12^{\mathrm{c}} \pm 0.16$ & $0.81^{\mathrm{c}} \pm 0.01$ \\
12.5 & $4.45^{\mathrm{b}} \pm 0.35$ & $11.85^{\mathrm{b}} \pm 0.32$ & $1.39^{\mathrm{a}} \pm 0.14$ \\
15.0 & $4.45^{\mathrm{b}} \pm 0.70$ & $13.49^{\mathrm{a}} \pm 1.29$ & $1.10^{\mathrm{b}} \pm 0.14$ \\
Control & $4.90^{\mathrm{a}} \pm 0.14$ & $4.95^{\mathrm{d}} \pm 0.11$ & $0.80^{\mathrm{d}} \pm 0.01$ \\
\hline
\end{tabular}

Values with the same superscript down the column were not significant different $(\mathrm{p}<0.05)$

Physicochemical composition of kunun-zaki sweetened with Thaumatococcus danielli: Physicochemical composition of Kunun-zaki sweetened with Thaumatococcus danielli are presented in Table 4. $\mathrm{pH}$ contents ranged from 3.51 to 4.90 . There were slight increases in the $\mathrm{pH}$ of kunun-zaki with increase in Thaumatococcus danielli addition. The control was significantly different $(\mathrm{p}<0.05)$ from other samples in pH.According to Kaanane, et al. (1998) the minimal change in $\mathrm{pH}$ can be explained by relationship existing between $\mathrm{pH}$ and free acid content. The high $\mathrm{pH}$ of a food is used as an indicator of bacterial spoilage i.e the food with high $\mathrm{pH}$ is more susceptible to microbial
Mean \pm Standard deviation

Physicochemical composition of Thaumatococcus dannielli aril: Physicochemical composition of Kunun-zaki with sucrose is shown in Table 3.pH ranged from 3.90-4.90. The $\mathrm{pH}$ of the control was significantly different $(\mathrm{p}<0.05)$ from other kununzaki samples. Increase in sucrose concentration reduced the $\mathrm{pH}$ of kunun-zaki. The $\mathrm{pH}$ of the samples increased as the values of sucrose increased, this may be as a result of the fact that, the samples were freshly prepared and the sugar in samples had not broken down as a result of fermentation. No significant differences $(\mathrm{p}<0.05)$ in $\mathrm{pH}$ values of sucrose concentration from 2.5 to $10.0 \mathrm{~g}$. $\mathrm{pH}$ is a measure of activity of the hydrogen ion and it measures the hydrogen ion concentration. $\mathrm{pH}$ is an index of the level of acidity or alkalinity of a sample and this has great effect on the storage period (Dandago, et al., 2004).This is in line with the report of Deans and Ritchie (2005) with $\mathrm{pH}$ of 4.67 for pawpaw juice. The titratable acidity of samples with $2.5 \mathrm{~g}, 5.0 \mathrm{~g}, 7.5 \mathrm{~g}$, and $10.0 \mathrm{~g}$ values of sucrose were significantly different $(\mathrm{p}<0.05)$ from others, while samples with $12.5 \mathrm{~g}, 15.0 \mathrm{~g}$ were not significant different $(\mathrm{p}<0.05)$. The total solids followed the same trend as titratable acidity in all the samples. There were no significant differences $(\mathrm{p}<0.05)$ in samples $12.5 \mathrm{~g}$ and $15.0 \mathrm{~g}$ sucrose. The control sample was significantly different $(\mathrm{p}<0.05)$ from other samples. Total solid is the amount of dry material remaining after all the water is evaporated.

spoilage. At high concentration (12.5 and $15.0 \mathrm{~g}$ ), the total solids were 7.43 and $7.23 \%$ respectively. There were no significant differences $(\mathrm{p}<0.05)$ in these values. Addition of Thaumatococcus danielli to kunun-zaki increased the total solids of kunun-zaki. Titratable acidity ranged from $0.74-0.85 \%$. Titratable acidity increased with increase in Thaumatococcus danielli concentration but there were no significant differences $(\mathrm{p}<0.05)$ among the kunun-zaki.

Table 4: Physicochemical composition of kunun-zaki with Thaumatococcus danielli

\begin{tabular}{llll}
\hline Sample $(\mathrm{g})$ & $\mathrm{pH}$ & Totalsolids & Titratable acidity \\
\hline 2.5 & $3.51^{\mathrm{d}} \pm 0.13$ & $5.33^{\mathrm{d}} \pm 0.16$ & $0.74^{\mathrm{a}} \pm 0.29$ \\
5.0 & $3.70^{\mathrm{d}} \pm 0.01$ & $5.81^{\mathrm{cd}} \pm 0.12$ & $0.77^{\mathrm{a}} \pm 0.10$ \\
7.5 & $3.57^{\mathrm{d}} \pm 0.07$ & $6.67^{\mathrm{b}} \pm 0.14$ & $0.82^{\mathrm{a}} \pm 0.01$ \\
10.0 & $3.75^{\mathrm{d}} \pm 0.13$ & $6.56^{\mathrm{b}} \pm 0.15$ & $0.85^{\mathrm{a}} \pm 0.01$ \\
12.5 & $3.97^{\mathrm{c}} \pm 0.42$ & $7.43^{\mathrm{a}} \pm 0.15$ & $0.85^{\mathrm{a}} \pm 0.04$ \\
15.0 & $3.96^{\mathrm{c}} \pm 0.14$ & $7.23^{\mathrm{a}} \pm 0.66$ & $0.83^{\mathrm{a}} \pm 0.07$ \\
Control & $4.90^{\mathrm{a}} \pm 0.14$ & $4.95^{\mathrm{e}} \pm 0.11$ & $0.80^{\mathrm{a}} \pm 0.01$ \\
\hline
\end{tabular}

Values with the same superscript down the column were not significant different $(\mathrm{p}<0.05)$

Comparative study on the physicochemical properties of kunun zaki with sucrose and Thaumatococcus danielli are 
shown in Table 5.Control had higher $\mathrm{pH}$ value which was significantly different $(\mathrm{p}<0.05)$ from other samples. This indicated that the control had higher tendency to deteriorate than other kunun-zaki. Kunun-zaki with $15.0 \mathrm{~g}$ sucrose had higher total solid while that with $12.5 \mathrm{~g}$ sucrose concentrations had higher titratable acidity which were significantly different $(\mathrm{p}<0.05)$ from other samples.

Table 5: Comparative study on the physicochemical properties of kunun-zaki with sucrose and Thaumatococcus daninelli aril

\begin{tabular}{|c|c|c|c|c|}
\hline Sample & $\begin{array}{l}\text { Concentration } \\
(\mathrm{g})\end{array}$ & $\mathrm{pH}$ & Total solids & $\begin{array}{l}\text { Titratable } \\
\text { acidity }\end{array}$ \\
\hline \multirow[t]{6}{*}{ Sucrose } & 2.5 & $3.90^{\mathrm{cd}} \pm 0.10$ & $9.15^{\mathrm{a}} \pm 0.22$ & $0.93^{\mathrm{C}} \pm 0.04$ \\
\hline & 5.0 & $4.00^{\mathrm{cd}} \pm 0.00$ & $10.23^{\mathrm{c}} \pm 0.14$ & $0.82^{\mathrm{cd}} \pm 0.28$ \\
\hline & 7.5 & $4.15^{\mathrm{bc}} \pm 0.07$ & $10.10^{\mathrm{cd}} \pm 0.14$ & $0.78^{\mathrm{d}} \pm 0.02$ \\
\hline & 10.0 & $4.40^{\mathrm{b}} \pm 0.14$ & $10.12^{\mathrm{cd}} \pm 0.16$ & $0.81^{\mathrm{cd}} \pm 0.01$ \\
\hline & 12.5 & $4.40^{\mathrm{b}} \pm 0.35$ & $11.85^{\mathrm{b}} \pm 0.32$ & $1.39^{\mathrm{a}} \pm 0.14$ \\
\hline & 15.0 & $4.45^{\mathrm{b}} \pm 0.70$ & $13.49^{\mathrm{a}} \pm 1.29$ & $1.10^{\mathrm{b}} \pm 0.14$ \\
\hline \multirow{6}{*}{$\begin{array}{l}\text { Thaumatococcus } \\
\text { danielli }\end{array}$} & 2.5 & $3.51^{\mathrm{e}} \pm 0.13$ & $5.33^{\mathrm{gh}} \pm 0.16$ & $0.74^{\mathrm{d}} \pm 0.29$ \\
\hline & 5.0 & $3.70^{\mathrm{cd}} \pm 0.01$ & $5.81^{\mathrm{fgh}} \pm 0.12$ & $0.77^{\mathrm{d}} \pm 0.10$ \\
\hline & 7.5 & $3.57^{\mathrm{c}} \pm 0.07$ & $6.67^{\mathrm{ef}} \pm 0.14$ & $0.82^{\mathrm{cd}} \pm 0.01$ \\
\hline & 10.0 & $3.75^{\mathrm{cd}} \pm 0.13$ & $6.56^{\mathrm{ef}} \pm 0.15$ & $0.85^{\mathrm{cd}} \pm 0.01$ \\
\hline & 12.5 & $3.97^{\mathrm{cd}} \pm 0.14$ & $7.43^{\mathrm{e}} \pm 0.15$ & $0.85^{\mathrm{cd}} \pm 0.04$ \\
\hline & 15.0 & $3.96^{\mathrm{cd}} \pm 0.14$ & $7.23^{\mathrm{e}} \pm 0.66$ & $0.83^{\text {cd }} 0.07$ \\
\hline control & & $4.90^{\mathrm{a}} \pm 0.14$ & $4.95^{\mathrm{h}} \pm 0.11$ & $0.80^{\mathrm{d}} \pm 0.01$ \\
\hline
\end{tabular}

Values with the same superscript down the col
$(\mathbf{p}<0.05)$
The Sensory Evaluation of Kunun-zaki with Thaumatococcus danielli aril and Sucrose: The mean scores for sensory characteristics of kunun-zaki with Thaumatococcus danielli and sucrose are presented in Table 6. The sensory data revealed that there were no significant differences $(\mathrm{p}<0.05)$ in the colour and aroma of the kunun-zaki. Taste of kunun-zaki with sucrose at $7.5 \mathrm{~g}$ concentration was preferred among the samples. Increase in Thaumatococcus danielli aril improved the taste of kununzaki but the tastes of kunun-zaki at higher sucrose concentration were not acceptable. Overall acceptability signified that kunun-zaki with low sucrose concentration (7.5g) were more acceptable than other samples followed by kunun-zaki with $2.5 \mathrm{~g}$ sucrose concentration and 15.0 $\mathrm{g}$ Thaumatococcus danielli aril. This showed that the higher the concentration of Thaumatococcus danielli aril, the higher the acceptability.

Table 6: Sensory Evaluation of kunun-zaki with Thaumatococcus danielli

\begin{tabular}{lllll}
\hline Sample & Colour & Taste & Aroma & Overall Acceptability \\
\hline $2.5 \mathrm{KZT}$ & $2.22^{\mathrm{a}} \pm 1.30$ & $2.00^{\mathrm{h}} \pm 0.00$ & $4.00^{\mathrm{a}} \pm 0.87$ & $2.56^{\mathrm{g}} \pm 0.88$ \\
$7.5 \mathrm{KZT}$ & $2.22^{\mathrm{a}} \pm 1.30$ & $3.56^{\mathrm{f}} \pm 0.53$ & $4.00^{\mathrm{a}} \pm 0.87$ & $2.78^{\mathrm{f}} \pm 0.83$ \\
$12.5 \mathrm{KZT}$ & $2.22^{\mathrm{a}} \pm 1.30$ & $4.60^{\mathrm{e}} \pm 0.88$ & $4.00^{\mathrm{a}} \pm 0.87$ & $4.44^{\mathrm{d}} \pm 0.88$ \\
$15.0 \mathrm{KZT}$ & $2.22^{\mathrm{a}} \pm 1.30$ & $6.11^{\mathrm{c}} \pm 0.61$ & $4.00^{\mathrm{a}} \pm 0.87$ & $5.11^{\mathrm{c}} \pm 2.32$ \\
$2.5 \mathrm{KZS}$ & $2.22^{\mathrm{a}} \pm 1.30$ & $7.11^{\mathrm{b}} \pm 0.61$ & $4.00^{\mathrm{a}} \pm 0.87$ & $7.00^{\mathrm{b}} \pm 2.65$ \\
$7.5 \mathrm{KZS}$ & $2.22^{\mathrm{a}} \pm 1.30$ & $8.89^{\mathrm{a}} \pm 0.33$ & $4.00^{\mathrm{a}} \pm 0.87$ & $7.33^{\mathrm{b}} \pm 2.78$ \\
$12.5 \mathrm{KZS}$ & $2.22^{\mathrm{a}} \pm 1.30$ & $2.89^{\mathrm{g}} \pm 0.33$ & $4.00^{\mathrm{a}} \pm 0.87$ & $2.56^{\mathrm{g}} \pm 0.53$ \\
$15.0 \mathrm{KZS}$ & $2.22^{\mathrm{a}} \pm 1.30$ & $4.78^{\mathrm{e}} \pm 1.40$ & $4.00^{\mathrm{a}} \pm 0.87$ & $3.22^{\mathrm{e}} \pm 0.83$ \\
Control KZ & $2.22^{\mathrm{a}} \pm 1.30$ & $5.45^{\mathrm{d}} \pm 0.88$ & $4.00^{\mathrm{a}} \pm 0.87$ & $4.56^{\mathrm{d}} \pm 0.73$ \\
\hline
\end{tabular}

Values with the same superscript down the column were not significant different $(\mathbf{p}<0.05)$

KZT= kunun-zaki with Thaumatococcus danielli, $\mathrm{KZS}=$ kunun-zaki with sucrose and control $=\mathrm{KZ}$

Conclusions: The result from proximate composition revealed that Thaumatococcus danielli aril has high protein which could be used as substitute for synthetic sugar since it is of calorie free. Also this fruit is one of the underutilized fruits which when processed can replace other sweeteners which can pose health challenge. Addition of more Thaumatococcus danielli aril to kunun-zaki could improve the acceptability of the product.

\section{REFERENCES}

Adeyemi, IA; Umar, S (1994): Effect of Methods of Manufacture on Quality Characteristics of kunun-zaki: A Millet Based Beverage. Nig. Food J. $12: 34-41$.

Amusa, NA; Ashaye, OA. (2009). Effect of Processing on Nutritional, Microbiological and Sensory Properties of Kunun-Zaki: A Sorghum Based Non-Alcoholic Beverage Widely Consumed in Nigeria. Pak. J. Nutri. 8(3): $288-$ 290.
AOAC, Official Methods of Analysis (2000). Association of Official Analytical Chemists 17th Edition USA: Washington D. C.

AOAC (2005). Official Methods of Analysis Association of Official Analytical Chemist $16^{\text {th }}$ Edition Washington D C.

Ayo, JA; Ayo, VA; Yelmi, B; Onuoha, G; Ikani, MO (2013). Effect of preservatives on microbiological qualities of kunu zaki.Int. J. Agric. Sci. Research 2: 124-130.

Butt, MS; Nasir, M; Akhtar, S; Sharifs, K (2004). Effect of Moisture and Packaging on the Food. J. Food Safety, 5-4

Cohen, S (2001). What's the Truth about the Health Risks of Sugar Substitute such as Saccharin and Aspartame? Health News 7(1): 10.

Dandajo, MA; Garba, R; Bahyo, EJ; Komolafe, GO (2004). Practical manual in Food Technology, Nutrition and Dietetics for Schools and 
Industries $\quad 2^{\text {nd }}$ Edn.Kaduna-Nigeria.National Science and Technology Forum, Kaduna Polytechnic.

Deans, SG; Ritchie, G (2005). Antibacterial Properties of Plant Essential Oil. Int. J. Food Microbiol. 5:167.

Faus, I (2000). Recent Developments in the Characterization and Biotechnological Production of Sweet - Tasting Proteins. Application of Microbial Biotechnol. 53(2): 145 $-151$.

Gaffa, TJ; Jideani, IA; Nkama, I (2002). Traditional Production, Consumption and Storage of Kununzaki: A Non-Alcoholic Cereal Beverage. Plant Foods Human Nutri. 57: $73-81$.

Gaffa, T; Ayo, JA (2002). Innovations in the traditional kunun-zaki production process. Pak. J. Nutri. 15: 202-205

Green, C (1999). Thaumatin: A Natural Flavour Ingredient. World Rev. Nutri. Dietetics 85: 129 132.

Hagiwara, A; Fakushima, S; Kitaori, M; Shibata, M; Ito, N (1984). Effects of Three Sweetners on Rat urinary Bladdar Carcinogenesis Initiated by $\mathrm{N}$ butyl-N-(4 - hydroxybutyl) - Nitrosamine 75(9): $763-768$.

Iwe, MO (2000). A Handbook in Sensory Methods and Analysis. First Edition Rejoints Communication Service Ltd, Uwani Enugu: 2000

Kaanane, A; Kane, D; Labuga, TP (1988). Time and Temperature Effect on Stability of Morrocan Processed Orange Juice during Storage. J. Food Sci. 53(5): 1470-1472

Kant, (2005). Sweet Protein: Potential Replacement for Artificial Low Caloric Sweeteners Nutri. J., 4,5 http://dxvw.ors110,1186/1475-291-4-5

Nabor, LO (1988). Saccharin and Aspartame are they Safe to Consume during Pregnancy? $J$. Reproduction and Medical, 33(8): 102.

National Research council (1989), Recommended Dietary Allowances $10^{\text {th }}$ edition. National Academy Press.Washington D.C USA.

Nkama, I; Adamu, I; Jalo, A (1995) Studies on the Preparation and Nutrient Composition of Kunun-
Gyada: A Traditional Nigerian Groundnut Cereal Based Beverage Weaning Food. Food Nutri. Bulletin 169: 238 - 240.

Novozamsky, I; Houba, VJG; Van, ECK; Van, VW (1983), Plant nitrogen and phosphorus in plant tissue, novel digestion technique for multielement. Plant analysis communication in soil science and plant analysis 14: 239-248.

Osuntogun, B; Aboaba, OO (2004). Microbiology and Physiochemical Evaluation of some NonAlcoholic Beverage. Pak. J. Nutr. 3(13): 188 192.

Oshodi, AA; Ogungbenle, HN; Olajide, MC (1999). Chemical Composition, Nutritionally Valuable Minerals and Functional Properties of Benni Seed (Sesamum radiation), Pearl Millet (Pennisetum typhoides) and Guinea (Chenopodium quinoa) flours. Int. J. Food Sci. Nutri. 50:325-33

Oyeyiola, GP (1991). Fermentation of Millet Product Akamu: A Nigerian Starch. World Microbial Biotechnol. 7: 196 - 201.

Raimi, DC; Elema, RN; Fatai, AA; Bankole, HA; Kazeem, MI; Banjoko, AO (2011). Isolation and Partial Characterization of a Protease Enzyme from Thaumatococus danielli Waste. Afr. J. Biotechnol. 10(16): 3186 - 3190.

Weihrauch, MR; Diehl, V; Bohlen, H (2002) Artificial Sweeteners: Are they PotentiallyCarcinogenic? Medical Klin (Munich) 96: $670-675$.

Yeborah, SO; Hulger, TH; Kroscrel, J (2008). Thaumatococcus danaelli, (Benn) Benth A Natural Sweetener from Rain Forest Zone in West African with Potential for Income Generation in small Scale Farming. Gottingen Technological and Institutional Innovations for Sustainable Rural Development: International Research on Food Security, Natural Resource Management and Rural Development. Book of Abstract Warten. 19.

Zemanek, EG; Wasserman, BP (1995), Issue and Advances in the Use of Transgenic Organism for the Production of Thaumatin, the Intensely Sweet Protein from Thaumatococcus danielli. Critical Rev. Food Sci. Nutri., 35(5): 61-65. 